\title{
Smrekov lubadar močno uničuje gozdove na zgornjem Gorenjskem
}

\section{Vida PAPLER LAMPE}

V GGO Bled je bila v letu 2007 zabeležena rekordna količina lubadark, kar je posledica zimskega snegoloma v letu 2007, ko je bilo na blejskem gozdnogospodarskem območju poškodovane približno 150.000 m3 lesne mase, od tega največ iglavcev. Močan napad lubadarja se stopnjuje v letu 2008, saj je bilo do začetka avgusta odkritih že približno $40.000 \mathrm{~m} 3$ lubadark.

Najbolj ogrožene lokacije so pobočja okoli Gorij, Radovna, Zgornjesavska dolina, bohinjska Spodnja dolina in širša okolica Radovljice. Do konca leta pričakujemo rekordnih $60.000 \mathrm{~m} 3$ lubadark, kar predstavlja tretjino poseka na tem območju. V letih 2007 in 2008 bo na območni enoti Bled zaradi podlubnikov na golo posekana površina gozda velika približno kot Blejsko jezero.

Na skalnih, zelo strmih legah (varovalni gozdovi) z lubadarji napadenega drevja ne sekamo. Tu zaradi varnosti ljudi pri delu gozd prepustimo naravnemu razvoju in skrbneje čistimo okoliške gospodarske gozdove.

Posek in spravilo opravlja v svojih gozdovih le še 5 \% lastnikov gozdov, drugo opravijo usposobljeni izvajalci. Teh v območju primanjkuje tudi zaradi izvajanja sanacije gozdov, poškodovanih v poletnih neurjih.

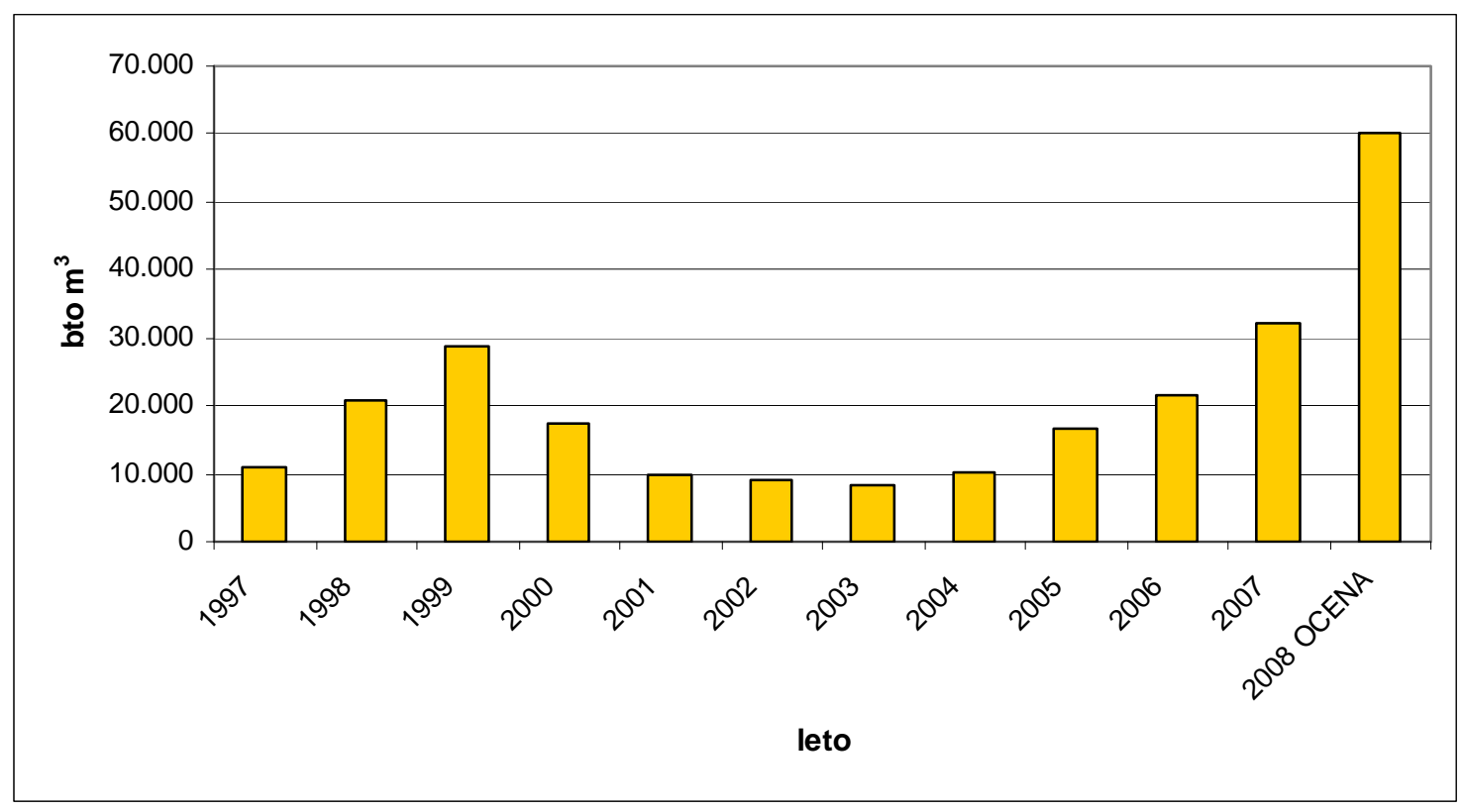

Slika 1: Posek drevja zaradi smrekovih lubadarjev v Gozdnogospodarskem območju Bled za obdobje 1995-2007 in ocena za leto 2008 